\title{
Tumor Tissue
}

National Cancer Institute

\section{Source}

National Cancer Institute. Tumor Tissue. NCI Thesaurus. Code C18009.

A tumor sample, or entire tumor that is removed for microscopic examination. 